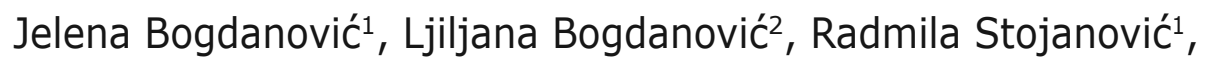
Radojka Đomlija ${ }^{1}$, Mila Maneski ${ }^{1}$, Maja Đorđević ${ }^{1}$, Dragana Popović ${ }^{1}$

\title{
TIREOTOKSIKOZA I KETOACIDOZA U BOLESNICE SA TDM1 - PRIKAZ SLUČAJA
}

Uvod: Tireotoksikoza je stanje sa viškom tireoidnih hormona. Najčešći uzrok je hipertireoidizam u Graves-ovoj bolesti, ali i toksičnoj polinodoznoj strumi, toksičnom adenomu. Uglavnom se javlja između 20. i 50. godine života, retko u starijih, najčešće u Graves-ovoj bolesti. Tireoidni dijabetes češći je u T1DM.

Bolesnica S. M., stara 21. godinu, primljena u MJ UC zbog mučnine, povraćanja, bola u trbuhu i povišene telesne temperature. Tegobe se javljaju četiri dana pre prijema. Lična anamneza: T1DM 11 godina, na intenzificiranoj terapiji insulinskim analozima (Novorapid i Levemir); hipertireoza godinu dana, na tireosupresivnoj tapiji (Tiastat), koju je samoinicijativno prekinula dve nedelje pre hospitalizacije. Bolesnica svesna, orijentisana, tahipnoična sa acetonemičnim halitusom, zažarena u licu, supfebrilna $\left(37.5^{\circ} \mathrm{C}\right)$, uredne omg i uhranjenosti, dehidrirana, vlažne kože, anksiozna. Palpira se difuzna struma gr III bez trila i vaskularnih šumova. Nad plućima vezikularno disanje. Akcija srca ritmična, tahikardična fr 130, bez šuma. TA $125 / 80 \mathrm{mmHg}$. Trbuh emk, palpatorno lako bolno osetljiv umbilikalno, bez organomegalije. Ekstremiteti bez edema. Laboratorijske analize: glikemija $15,7 \mathrm{mmol} / \mathrm{L}$, urea 7,5, kreatinin $53, \mathrm{~K}$ 4,9, Na 141, Cl 107, pH 7,12, HCO3 5,50, Le 19,3, SE 20, CRP 33,0, HbA1c 8,2\%, $\mathrm{TSH}<0,01$, FT 322,86, FT4 57,1. EHO vrata: Štitasta žlezda uvećana, nehomogena sa grubim septama. CD signalizacija pojačana. Reaktivne lgl do $6,5 \mathrm{~mm}$ sa obe strane.

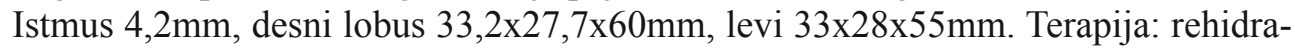
tacija, insulin i.v., $\mathrm{H}_{2}$ blokator, antiemetik, antibiotik, kortikoterapija, jod kontrast iv, PTU 800mg potom 400mg, beta blokator.

Zaključak: Koncentracija tireoidnih hormona utiče na cirkulišući insulin, intestinalnu apsorpciju i hepatičnu produkciju glukoze, kao i vezivanje glukoze u perifernim tkivima. Udruženost ove dve endokrinopatije zahteva redovnu kontrolu jednom godišnje, odnosno održavanje zadovoljavajuće glikoregulacije i eutiroidnog stanja.

\footnotetext{
1 Metabolička jedinica, Urgentni centar, Klinika za endokrinologiju, dijabetes i bolesti metabolizma, Klinički centar Srbije
}

2 Institut za patologiju, Medicinski fakultet Univerziteta u Beogradu 